\title{
MEDICINE AND THE BAR.
}

To the Editors of THE LANCET.

SrRs, -I send you this chronological record of medical practitioners who have been called to the English Bar. I have also a few similar names of solicitors, of Irish barristers, and of graduates in Law. If any of your readers are able to amplify or to correct the appended list I should be very grateful. I am, Sirs, yours faithfully,

STANLEY B. ATKINSON,

Joint Honorary Secretary of the Medico-Legal Society.

10, Adelphi-terrace, W.C., October, 1905.

1763 ,

1790 ,

Sylvester Douglas
(Lord Glenbervie), $L^{*}$

Thomas Addis Emmet (Irish Bar).

1795, James Mackintosh (Kt.), $L$.

1811, Henry Bickersteth (Lord Langdale, M.R.), $I$.

1835, June, Charles Wilkins (Sjt.),

1837, Nov., Samuel Warren (Q.C.), I.

1854, Nov., Watkyn Williams (Mr. Justice), $I$.

1865, Nov., Edward Cooper Willis (K.C.), $I$.

1867, Nov., Robert Bannatyne Finlay (Kt., K.C.), M.

1872, Nov., Edward James Pollock, $I$.

1878, May, George Vere Benson,

1883, April, Arthur Dudley ParrDudley, $L$.

June, Horace New begin Watts, $L$.

1884, June, Thomas Faris, $I$. Tohn Percival Hunt, $L$,

1885, Nov., Charles Gross, $M$. Cyril Lloyd Jones, $M$.

1886, May, S. A. K. Strahan, $M$.

1887, June, Henry Smith, $L$.

1888, April, William Robert Smith,

$M$.
June, Henry Cooper Rose, $M$.

1889, July, A lexander Wynter Blyth, $L$.

Charles Meymott Tidy, $L$.

1890, Nov,, Cliff or d Luxmoore Drew, $M L$

Bernard O'Connor, $G$

Harry Walter Verdon, $M$.

1891, April, George Francis Pires, $M$. Meorge Eugene Yarrow, $G$.

1892, Jan., J a m es Griers on Gledhill, $M$.

July, Josiah Oldfield, $L$.

Edward John RocheSurrage, $M$.

1893, April, John Edwin Cooney, $M$. June, H. S. Maurice, $L$. George Herbert Pollard, $I$.

Derwent Hutton Ryder Waldron, $L$.

Nov., S hapor ji Aspaniar Kapadia, $I$.

1894, Jan., Hugh Morgan David son, $M$.

Thomas Ernest Saunt

April, William Jackson, $I I$ Henry Robert Oswald, Henr.

Nov., Norman Bruce Elliot, Trnest Henry Cartwright. $M I$.

June, William McCallin, $r$.

1896, April, Sidney Reginald Dyer,
1896, April, William Murray Leslie, $M$ Frederick Joseph Waldo, $M$.

June, Allan MacLean, $I$.

Nov. Frederick, Charles Goodwin, $G$ Major Greenwood, $L$.

1897. Jan., Richard Deane Sweeting, $G$.

William Owen Travis,
June, Samuel Fleming,

Nov., John Patrick Walsh, $L$. harles Frederic Rumboll, $I$.

1898, June, Charles Williams Hayward, $G$.

1899, Jan., John Richmond Bryce, $r$.

April, Stanley Bean Atkinson, $I$.

June, George Russell Beardmore, $I$.

William Henry Coates, Herbert Evelyn Crook,
Hel $M$.

Ludwig Freyberger, $M$. Robert Iyall Guthrie, Ir. Charles Porter, $G$.

1900, June, William Sellers, $M$. Charles Henry Wise, $I$. 1901, June, Sarnuel Ingleby Oddie, $M$.

Arthur Hope Taylor, $M$.

Rowland Philip Williams, $G$. Nov., George Fitz james

1902, Jan., John Shives, $M$. William Clunie Wise W.

April, Thomas Fentem, $M$. F d m und Thoma Whitaker, $I$.

June, George Herbert Coke $M$.
John Henry Garrett, $M$.

Nov, George Chadwick Kingsbury, $M$ Arthur Henry Thomp son, $L$.

1903, May, James Henry Farls, $M$ Frederick Harvey Norvill, $I$.

June, Edward Birchal Sherlock, $M$ Daniel Lewis Thomas

$G$.
Nov., Thom as Hillier Chittenden, $I$. Arthur Douglas Cow burn, $\boldsymbol{M}$.

1904, Jan., Tom Eastham, L. Lew is Lewis, $M$. John Vernon Rees Roberts, $L$. Donald Georg Sutherland, $M$

April, Digby Cotes-Preedy, $I$ 1905, Jan., William Alfred Brend, $I$ Ernest Hugh Snell, $M$.
. Now o o j i Merwanji
Tarachand, $M$.

July, William Robert Bryett, John Francis ButlerHogan, $G$.
Harold Coates, $G$. James Scott Tew, $I$. Frederick 5 he $\mathbf{r m}$ a Toogood, $M$.

\section{EMPHYSEMA OCCURRING DURING PARTURITION.}

\section{To the Editors of THE LANCET.}

SIRs, - In your issue of Oct. 28th Mr.F. H. Sprague describes a case of emphysema occurring during parturition. In this note, as in others reported from time to time, the statement is repeated that "the effusion of air into the connective tissue spaces is the result of rupture of some of the air vesicles of the lungs due to the excessive straining caused by the violent labour pains." Such an explanation may be true of a case when there are adhesions between the visceral and parietal pleuræ and breaking down of tissue from active disease. The air might then escape directly into the subcutaneous tissue of the chest wall and spread thence to the neck and face. But this must be very exceptional. As a matter of fact, emphysema usually occurs in robust and muscular subjects without any symptoms of past or present lung trouble and in these cases, if rupture of air vesicles were the primary lesion, the course the air would require to traverse before reaching the subcutaneous tissue of the neck would be as follows. Gaining the connective tissue of the lung the air would pass through the root of the lung into the connective tissue of the posterior wall of the thorax, upwards into the deep connective tissue of the neck, and then would have to break through the deep and superficial cervical fascize before reaching the situation in which it is ultimately found. This, as I have proved on the cadaver, is a physical impossibility. With a syringe the connective tissue of the lung can be infiltrated with air when the chest is opened and the lungs collapsed, but the air will not pass through the root of the lung nor through the fasciæ of the neck.

A much simpler explanation of this form of emphysema, and one which can be demonstrated on the cadaver to be feasible, is that the air gains access to the submucous tissue in the upper air passages, most commonly, I believe, at the lips, which have been bitten by the frenzied patient, and spreads over into the subcutaneous tissue of the same side of the face, neck, and chest. A similar condition has been produced in attempts to politzerise the Eustachian tube through a catheter. In Mr. Sprague's case the emphysema invaded the submucous tissue of the throat, impeding breathing, speaking, and swallowing. In injecting air into the submucous tissue of the mouth it easily passes backwards underneath the mucous membrane as well as forwards over the lips underneath the skin. It would be interesting to know if emphysema of the mucous membrane of the mouth, nose, or throat has been looked for by anyone who has seen cases of this complication of labour.

Glasgow, Oct. 30th, 1905. I am, Sirs, yours faithfully,

\section{THE FALLING BIRTH-RATE.}

\section{To the Editors of THE LANCET.}

SIRs,--In the Bishop of London's charge to his clergy he boldly attacked a great sociological question and one of interest to the medical profession. He deplored the falling birth-rate in this country. His lordship is to be congratulated upon dealing with a matter fraught with so much difficulty and delicacy and yet one of such practical importance not only to the Church but to the nation. The problem is by no means an easy one. It is the burning question in France to-day and many suggestions have been put forward to stem the steady decline in that country where the birth-rate has fallen in the last century from $32 \cdot 3$ per 1000 to $23 \cdot 4$. The Bishop admitted that in all the other European countries, with the exception of Russia, there was a falling birth-rate. He appears to regard it as proved that this almost universal decline is due to the prevention of conception by artificial means. But is this altogether true? I very much wonder. Doubtless the prevention of conception and limitation of families are enormously on the increase in all Western countries-always excepting Russia, which is scarcely Western-but there is another factor making largely for a falling birth-rate, and that is later marriages. I will not weary you with figures, but both in England and France the age at which marriages take place is assuredly getting later-this means fewer years of probable fertility.

The exception of Russia in the general decline is significant. Those who have been in that country know that only a small proportion of its millions have been really brought under the influence of Western habits that go by the name

* I., M., L., G., indicate the Inn of Court which " called." 